\title{
How Can Service Failures Be Recovered? Start with Star Ratings, Personnel Rank, and Failure Severity
}

\author{
Wen-Chin Tsao ${ }^{1}$, Yu-Shan $\mathrm{Lin}^{2}$, Yu-Chen $\mathrm{Liu}^{3}$, Qi-Xin $\mathrm{Chen}^{3}$, Shu-Fen $\mathrm{Li}^{3}$ \\ ${ }^{1}$ Professor, Department of Business Administration, National Chin-Yi University of Technology, Taichung, \\ Taiwan, Republic of China \\ ${ }^{2}$ Postgraduate of Department of Business Administration, National Chin-Yi University of Technology, Taichung, \\ Taiwan, Republic of China \\ ${ }^{3}$ Undergraduate student of Department of Business Administration, National Chin-Yi University of Technology, \\ Taichung, Taiwan, Republic of China.
}

Correspondence: Wen-Chin Tsao, Professor, Department of Business Administration, National Chin-Yi University of Technology, Taichung, Taiwan, Republic of China.

\author{
Received: April 28, $2020 \quad$ Accepted: May 29, $2020 \quad$ Online Published: June 4, 2020 \\ doi:10.5539/ibr.v13n7p56 URL: https://doi.org/10.5539/ibr.v13n7p56
}

\begin{abstract}
In recent years, companies have had to continuously pursue higher service quality and maintain customer satisfaction because of rising consumer awareness. Due to the special industry attributes of the service industry, it is particularly important for the service industry to recover service failures. The purpose of this study is to explore how to propose the solutions from the constructs of hotel star ratings, service staff ranks, and service failure severity. Eight scenarios were constructed by experimental design, which were performed on the network platform to collect data. A total of 320 subjects participated in this study. The results of this study show that hotel star rating and service staff rank can affect post-recovery satisfaction. In addition, the three variables of hotel star rating, service staff ranking, and service failure severity will affect corporate image. Finally, this study has also verified that better post-recovery satisfaction will help improve corporate image. Managerial implications for the marketing managers of the hotel industry and directions for future research are also discussed.
\end{abstract}

Keywords: hotel ratings, service failure severity, post-recovery satisfaction, corporate image, star ratings, service recovery

\section{Introduction}

Due to the popularity of business and improved transportation convenience, the number of visitors to Taiwan for tourism or business purposes has increased year by year, and the demand for hotel accommodation has also increased. For customers, a product purchase eventually leads to experience and memory; therefore, for hotel managers, how to create a deep impression for the guests regarding the service of the hotel, which allows them to experience and enjoy the hotel services, is an important issue (Tseng \& Chang, 2012). Hotels not only provide a comfortable environment for rest and amenities to meet the needs of their guests, depending on the different grades and specifications of the hotels, they also offer additional facilities and services that are not core services, thereby, enhancing the perceived value and satisfaction of guests (Tsao, 2018).

Due to the characteristics of intangibility, inseparability, variability, and perishability of the service industry, coupled with customer participation in the service delivery process, service failures are unavoidable (Tsao, Hsieh, Ye, \& Tsai, 2014; Tsao \& Jhang, 2019). Since service failures cannot be avoided, a good service recovery mechanism has become an important management mechanism to retain customers and avoid customer defection (Tsao, 2018). Moreover, with superior service recovery, the customer's overall satisfaction with the service may exceed the satisfaction with no failures at all, resulting in a second satisfaction, which shows the importance of service recovery in the service industry.

Knutson (1988) conducted research on the reasons that frequent hotel customers for their choices of hotels and becoming frequent guests in the United States. The investigation found that hotel rank was one of the reasons. There are many ways of ranking hotels in the world. In Taiwan where the American Automobile Association (AAA) system is followed, the star rating system is used to distinguish hotel ranks (Tsao, 2018). Star rating is an 
objective certification that provides the promise of different quality of goods and services to guests, and also represents the price consumers pay for different levels of hotel quality (Ariffin \& Maghzu, 2012). Facing the same service failure that occurs in different star-rated hotels, consumers will have different levels of requirements for recovery. Therefore, this study believes that hotel star rating may affect the effectiveness of recovery. In addition, when a service failure occurs, the hotel must dispatch staff to deal with it quickly; however, the level of the person who responds to the problem represents the company's attention to the failure, and thus, the customer experience. According to the service quality model proposed by scholars, higher-level managers will allow consumers to experience higher perceived service quality, which it is bound to expand the gap 5 in the model, thus, affecting consumer satisfaction with recovery (Parasuraman, Zeithaml, \& Berry, 1988). Furthermore, a more serious service failure means that the company must spend more effort to make up for the dissatisfaction of consumers; therefore, the severity of the service failure may also affect the effectiveness of recovery.

In the past, most related studies only discussed how service quality affects customer satisfaction, or the remedial effect was explored by the attractiveness and gender of service personnel, as based on the perceived justice theory (Tsao \& Jhang, 2019). There are few researches on the three constructs of hotel rating, personnel rank, and service failure severity to explore the relationship between them, post-recovery satisfaction, and corporate image. Therefore, this study attempts to explore the benefits of recovery from the attributes of hotels, personnel, and erroneous events, and proposes the establishment of an excellent recovery mechanism. It is intended that the findings of this study will be of practical help to the hotel industry in its service failure recovery strategies.

\section{Literature Review and Hypotheses}

\subsection{Hotel Rating}

The hotel industry is an important part of tourism development. Consumers are not only asking for the safety of their accommodations, they also put more emphasis on the hotel atmosphere, style, and rating. There is currently no universal standard for hotel rating mechanisms. In order to protect international travelers and allow them to obtain more objective and consistent accommodation information during cross-border travel, the World Tourism Organization (WTO) and the International Hotel \& Resorts Association (IH \& RA) have proposed several views on the spirit and concept of star ratings to members for reference (Tefera \& Govender, 2015; Tsao, 2018). Hotel rating systems are not introduced in every country's hotel industry, and even if it is introduced, the attributes or rating standards of evaluation units in different countries will vary due to differences in politics, law, economy (tax considerations), or culture (customs and values), thus, there are different interpretations of the meaning of hotel quality grades in various countries (Yu, 1992; Stapp, 2012; Su \& Sun, 2007; Tsao, 2018). Currently, the more internationally recognized or cited systems are the American Automobile Association (AAA) system, Mobile Travel Guide, Forbes Travel Guide, and the UK rating scheme (Tsao, 2018; Sun \& Sun, 2007; Wu, 2011). The Ministry of Transportation and Communications (Taiwan) launched a hotel evaluation system based on the AAA system in 2015 with the number of stars as the evaluation unit; the lowest level is one star and the highest is five stars (Tsao, 2018).

When consumers choose a hotel, in addition to the price, the attributes of the hotel's brand image and rank are symbolic benefits that are also important references (Tsao et al., 2014). Different stars lead the hotel to formulate its market segmentation and value positioning, which means to provide different overall service levels to a given target market (Tourism Bureau, 2008; Wu, 2011). Generally speaking, higher-ranking hotels represent the hotel's commitment to providing quality services to guests and the level of service expected by guests (Bhavani, 2013; Ariffin \& Maghzi, 2012). The price-quality schema theory believes that price is an important clue that affects consumers' perceived quality of products/services, meaning consumers generally believe that the price paid is positively related to the quality obtained (Byun \& Chatterjee, 2004). Therefore, the higher the star-rated hotels, the higher the room rates; higher room rates will also prompt consumers to expect and demand higher quality of service (Öğüt \& Onur Tas, 2012). Therefore, this study incorporated the hotel star rating into the discussion of service recovery.

\subsection{Personnel Rank}

In the hotel industry, when guests have any needs, service personnel are required to provide appropriate and reasonable services to guests. Therefore, the role of service personnel in the hotel industry is as critical as the role of human blood for the functioning of the body, thus, service personnel is one of the important core elements of hotel operations. Compared with other service industries, hotel guests must visit the service site (meaning service factory), and must be in full contact with the service provider (including service personnel and physical facilities) during the service delivery to obtain the experience; therefore, there is a high degree of contact 
between service providers and guests during the process of complete service implementation (including failure recovery) (Tefera \& Govender, 2015; Tsao, 2018). Especially, when a service failure occurs, the hotel must dispatch personnel to resolve it as soon as possible. Based on the price-quality schema theory, the rank of the person who resolves the failure will affect the customer's expectations of the quality of service recovery (Byun \& Chatterjee, 2004).

In addition to serving as the core role in decision-making, senior executives have important tasks for industries with service characteristics, such as hiring and selecting low-level employees, education and training, rewards, technical support, authorization, and evaluation of performance (Rogg, Schmidt, Shull,\& Schmitt, 2001). The key to the direction and development of a company is that senior executives make decisions based on the company's various resources, which clearly indicate its future development direction (Drucker, 1993). Low-level service personnel are often referred to as front-line service personnel; in addition to being intelligent and physically fit, this position also requires additional "emotional labor" (Chen, 2009). When customers encounter service dissatisfaction, they usually complain to frontline service personnel as soon as possible, and the first-line service personnel's good or poor handling of customer complaints or response methods will be an important key for customers first impression of a company. Therefore, the attitudes and processes of frontline employees in handling incidents of failures will affect customers' perceptions of post-recovery satisfaction and corporate image (Hartline \& Ferrell, 1996).

\subsection{Service Failure Severity}

Scholars have different definitions of service failure. Palmer, Beggs and Keown-McMullan (2000) indicated that when the customer thinks the service is flawed or irresponsible, it is a service failure. Some studies have suggested that when the customer deems that the service has not been performed, delayed, failed, etc., it results in a failure to reach the expected level, and is a so-called service failure (Bitner, Booms, \& Tetreault, 1990). It is known that service failure means the quality of the service delivery process or the end result of the customer's subjective perception is lower than the expected service level or lower than the zone of tolerance, which leads to dissatisfaction and complaints about the service (Tsao, et al., 2014; Tsao, 2018). Judgment of the severity of a service failure may depend on the individual's internal emotions and external context (Hoffman \& Kelley, 2000). Every customer has a tolerance zone for mistakes, and each customer's tolerance zone is different (Grönroos, 2000). Service recovery becomes more difficult when customers consider this failure to be serious (Mattila, 1999; Smith \& Bolton, 1998).

\subsection{Post-recovery Satisfaction}

Compared with other service industries, employees in the hotel industry usually have a higher degree of involvement when delivering services, resulting in a higher probability of service failures than other service industries (Lewis \& McCann, 2004; Petzer \& Steyn, 2006; Tsao, 2018). Since service failures are inevitable, good service recovery mechanisms are important for the recovery of enterprises (Tsao, 2018). Post-recovery satisfaction (PRS) refers to the company's response to customer complaints, as well as the process of handling problems, and it is a remedial action taken to the substantial damage to customers or loss caused by not meeting customer expectations (Hart, Heskett, \& Sasser, 1990). Hart et al. (1990) suggested that service failures may not necessarily cause customer dissatisfaction; as good failure recoveries can make up for customer dissatisfaction; if the recoveries are appropriate, second-time satisfaction can enhance and strengthen customers' long-term loyalty relationship with the company (Tsao et al., 2014).

\subsection{Corporate Image}

Image refers to the consumer's subjective perception of the entity, which is the perception and evaluation of consumers based on personal values after they receive information. Walters and Paul (1970) indicated that corporate image refers to people using friendly, reputable, and reliable adjectives to describe their impression of the company. Dowling (1986) argued that image is the relevance generated by people's description, memory, or other things; this means it is the final result of a person's beliefs, thoughts, feelings, and impressions on an object. Therefore, image is a subjective cognition when people have a special knowledge or opinion about something they know. Image can be applied to measure several aspects, including business, brand, individual, product, employer, or other. According to the purpose of this study, the dependent variable of is set as corporate image, and it was attempted to explore how the effectiveness of failure recovery affect corporate image.

\subsection{Hypothesis Development}

\subsubsection{Impact of Star Rating, Personnel Rank, and Service Failure Severity on PRS}

Compared with the hotel's size and location, the star rating system is an objective and complete rating system, as 
different star ratings can show the overall level of the hotel's software and hardware. This objective rating is better than other single or subjective requirements in effectively forming customer expectations (Ariffin \& Maghzu, 2012). It is pointed out that star rating can be regarded as an explicit service promise, and will affect consumers' expectations for service quality. According to the ELM theory, consumers consider a star rating as a peripheral cue that helps them consider service quality and form attitudes (Petty \& Cacioppo, 1986; Tsao, 2018). Some consumers have mentioned that higher-star hotels should provide higher service quality and better facilities, thus, they will have a better attitude towards high-star hotels and higher service performance expectation (Zeithaml et al., 2006; Ariffin \& Maghzu, 2012; Ramanathan \& Ramanathan, 2013). Based on the above literature, this study believes that the service recoveries of higher-star hotels will make customers more aware of good service quality than lower-star hotels, which will help improve customer satisfaction; therefore, the following hypothesis is proposed:

H1: High-star hotels can significantly improve PRS compared to low-star hotels.

Huppert, Arenson and Evans (1978) presented the concept of the equity theory, as proposed by Adams (1963), into the service industry's marketing field. From the perspective of hotel characteristics, customers' perception of fairness will be judged according to the overall cost (money, time, physical strength, and psychology) and benefits (accommodation experience, hotel image, service, and psychology) of the hotel. Only when customers perceive that the overall benefit is greater than or equal to the cost, can they feel fair and satisfied. Blodgett, Hill and Tax (1997) expanded the equity theory to service failure handling, in order to understand how customers are satisfied with the recoveries provided by the industry after service failures. Since then, scholars have generally used the three justice aspects of distributive justice, procedural justice, and interactional justice to discuss issues related to service failure and recovery (Goodwin \& Ross, 1992; Smith, Bolton, \& Wagner, 1999; Tsao, 2018). Interactional justice refers to the extent of fair treatment felt by customers when they assess their communication and interaction with service personnel during service recovery (Maxham III \& Netemeyer, 2002).

When the person performing remedial work is a high-level person, based on interactional justice, this study believes that it will help improve the customer's inner feeling and respect, and increase the customer's inner perception of justice, which will increase satisfaction. Therefore, this study suggests that when a service failure occurs, the level of responding personnel will affect the perception of how much the company values the customer; higher-ranking staff will be more helpful than lower-ranking service staff. Therefore, this paper proposes the following hypothesis:

H2: Higher-level service personnel can significantly improve PRS than lower-level service personnel.

Research has shown that when the severity of service failures is higher, customers are more inclined to negative emotions and their satisfaction is lower (Hoffman, Kelley, \& Rotalsky, 1995). Distributive justice refers to the extent of fair treatment felt by customers for the tangible or substantive outcome of customers' service recovery. Based on scholars' arguments, the substantial financial compensation outcomes are varied, such as cash discounts, discount coupons, return and exchange, and free commodities (Maxham III \& Netemeyer, 2002). If the service failure is greater, companies often need to pay more substantial compensation to make up for the customer's internal dissatisfaction. Based on the theory of distributive justice, this study believes that large service failures require more financial make-up than small failures to improve consumers' inner awareness of justice, and it is less easy to improve perceived justice; therefore, this study proposes the following hypothesis:

H3: The higher the severity of the service failure, the more negative the impact on PRS.

\subsubsection{Impact of Star Rating, Personnel Rank, and Service Failure Severity on Corporate Image}

Nguyen and Leblanc (2001) suggested that the overall perception of customers about corporate entities and behaviors is the so-called corporate image. The source of image formation comes from the multiple aspects of the company's name, culture, business philosophy, and products/services. The quality of the corporate image is also an important indicator for consumers' behavior to choose a store. In addition to the corporate image of the hotel, the star level is another factor affecting consumers' decision to stay (Tsao, 2018). Customers often have high expectations for high-star hotels, meaning they also expect better service; in contrast, while they do not have any additional high requirements of low-star hotels, they still need to have their comprehensive basic needs met; accordingly, the following hypothesis is proposed:

H4: High-star hotels can significantly enhance corporate image than low-star hotels.

Customers' impressions of service personnel are often passed on to the corporate image. Service personnel are divided into different levels of employees for the operations of corporate organizations, and low-level service 
personnel are the main service providers that are often the first company employees to contact with customers. Keller (2000) pointed out that employee behavior performance is an important factor affecting customers' formation of a good corporate image. High-level service personnel generally play the role of decision-makers behind the scenes; however, when they appear on public occasions on behalf of the company, it indicates that they attach more importance to the incident, which will be more helpful for improving the corporate image. Procedural justice in the justice theory refers to the extent to which customers are aware of the justice of recovery policies and procedures during the recovery process. When higher-level personnel have greater authority than lower-level personnel, it is conducive to the smooth implementation of the recovery process, and helps to improve the customer's perceived procedure justice, which in turn improves the company's good image in the customer's mind; hence, this study proposes the following hypothesis:

H5: Higher-level service personnel can significantly improve corporate image than lower-level service personnel.

According to Richins (1983) on negative word-of-mouth due to customer dissatisfaction, the worse the customer feels about service failures and the worse the company's recovery for customers, the greater the amount of negative word-of-mouth generated. Dissatisfaction and negative word-of-mouth caused by more serious mistakes will cause customers to have a bad perception of the company's image, which will further affect their next purchase intention. In terms of the severity of service failures, the companies with relatively good reputation are better able to take remedial measures, reduce customer dissatisfaction, and maintain relationships with customers when service failures are more moderate; when the service failure is serious, it is difficult to recover and prevent customer dissatisfaction, or maintain the relationship with each other, regardless of the company's good reputation (Hess, 2008). Therefore, when the service failure is more serious, according to the equity theory, the company will definitely need to make more substantial or intangible investment to make up for the loss of consumers' internal feelings, which will indirectly and negatively affect consumers' satisfaction with the recovery, and thus, affect the corporate image. Accordingly, this paper proposes the following hypothesis:

H6: The higher the severity of the service failure, the more detrimental to the corporate image.

\subsubsection{Relevance between Post-Recovery Satisfaction and Corporate Image}

The corporate image after recovery refers to the customer's recognition of the corporate image after recovery when service failures occur (Chen, Chen, Chang, \& Wang, 2018). Scholars argue that a high degree of satisfaction will reduce the cost of failure of the company, and thus, enhance its reputation. Good remedies not only retain dissatisfied customers, but also improve corporate image (Fornell, 1992; Yoo, Park, \& MacInnis, 1998; Clark, Kaminski, \& Rink, 1992). Tsao (2018) found that when a company makes mistakes, if the customer feels that the treatment process is fair in procedure, interaction, and distribution, the post-recovery satisfaction will be improved, and then, customer loyalty (positive word-of-mouth and willingness to repurchase) will be improved, and customer defection will be reduced (Tsao, 2018). With the positive word-of-mouth of consumers, it is expected that the corporate image will be positively improved. Thus, this paper proposes the following hypothesis:

H7: Post-recovery satisfaction has significant positive impact on corporate image.

Figure 1 presents the conceptual model of this study, as based on the aforementioned literature and hypotheses. 


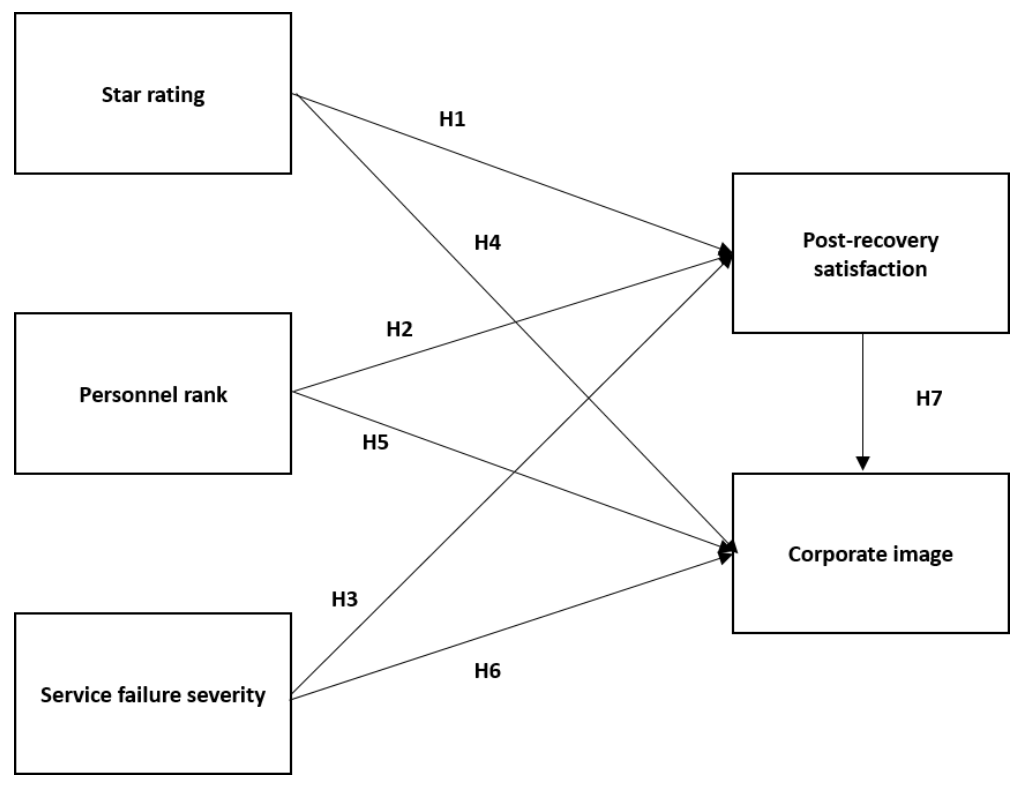

Figure 1. Conceptual research model

\section{Methods}

\subsection{Research Design}

Without external intervention, it is usually more difficult to measure the subject's service experience by consumer recall, especially when service failures and recovery are involved (Tsao, 2018). To enhance the internal validity of the study, this study adopted an experimental design method. By manipulating different failure scenarios, the subjects were made to feel like they were in the real situation, in order to observe their most intuitive responses to the situation stimulus. This study used a 2 (star rating: high and low) $\times 2$ (personnel rank: high and low) $\times 2$ (service failure severity: high and low) between-subject factorial design. Each subject was designated to one of eight scenarios for the experiment.

\subsection{Development of Stimuli and Measures Development}

To reach the appropriate subjects, guests who had actually stayed in the hotel were taken as the research subjects of this study. According to the research purpose, the experimental scenario was designed with a total of 8 virtual scenarios, and the subject filled in the questionnaire after seeing the scenario text. The first part is the description of the failure scenarios, including the level of the star rating and the process of the service failure. The second part is the description of the recovery scenarios, including the recovery staff (service staff of different ranks). After reading the scenarios, the subjects filled in the relevant items of the questionnaire, including post-recovery satisfaction and corporate image. An identification question was used in the questionnaire to screen invalid questionnaires.

First, the manipulation of high and low star ratings in this experimental hotel are explained. According to previous relevant star literature and Taiwan's evaluation regulations, this study used the factors of Taiwan's star hotel evaluation, as published by the Tourism Bureau (2016), with one star $(\star)$ representing low star rating and five stars $(\star \star \star \star \star)$ representing high star rating for the manipulation of hotel star ratings in virtual text. Regarding the rank of service personnel, in this study, the rank manipulation of processing personnel was performed with front-line service personnel representing low-level positions, and managerial positions representing high-level positions (Chen, 2009; Hsieh, 2016). This study is based on the investigations of nine failures conducted by previous research for hotel service failures (Pranic \& Roehl, 2012; Lewis \& McCann, 2004), which are measured by the severity of the failures. Finally, high-severity failures are represented by "hotel smells", and low-severity failures are represented by "incorrect hotel bills".

PRS is called second-time satisfaction, which refers to the customer's overall satisfaction after remediation by the company when a service failure occurs, which is different from the first-time satisfaction obtained when customers enjoy the service before the failure occurs (Smith et al., 1999; McCollough, Berry, \& Yadav, 2000). This study referred to the following five measurement questions to measure PRS, as proposed by the study of del Río-Lanza, Vázquez-Casielles \& Díaz-Martín (2009): (1) After the hotel recovery, I was satisfied with the way 
the problem was handled; (2) After the hotel recovery, I was satisfied with the service staff's attitude/method to solve the problem; (3) After the hotel recovery, I was satisfied that the problem had been properly responded to; (4) After the hotel recovery, I was satisfied with the way the hotel provided recovery; (5) After the hotel recovery, I have a better rating for this hotel on the whole. All items were measured using a seven-point Likert-type scale, ranging from one (strongly disagree) to seven (strongly agree).

This study considers corporate image to be the subjective cognition born of the experience, feelings, ideas, and interactions between enterprises and consumers, as well as the mutual impacts of such knowledge (Brown \& Worcester, 1972). This study referred to the following four questions to measure corporate image, as proposed by Riordan, Gatewood \& Bill (1997): (1) I have a better impression of the hotel; (2) The service attitude of the hotel is good and impressive; (3) I think the hotel has a good overall image; (4) I have a positive evaluation of the hotel's services. All items were measured using a seven-point Likert-type scale, ranging from one (strongly disagree) to seven (strongly agree).

\subsection{Experimental Procedure and Participants}

In order to meet the purpose of this study, the participants were consumers who had stayed at hotels in the past year. The network was used to conduct experiments and collect subject responses. This study used the Wix.com web editor to edit the questionnaire and smooth the test flow. The network platforms utilized include Facebook and the questionnaire exchange community. The researchers placed the online links of the eight contextual texts on the platform, in order to allow the invited participants to freely choose the experimental scenarios. In order to reduce sampling bias and make non-random sampling as random as possible, the order of placement of the experimental context links on the platform was changed from time to time, thus, the placement of experimental context links did not allow the scenario of a certain position to influence researchers' preferences after the subject entered the platform.

After the subjects chose a certain situation link, they entered the stage 1: feeling the service failure. The subjects first read the description of the hotel characteristics and the accommodation scenario description ( 5 stars or 1 star manipulation), and then, the service failure scenario description was presented (manipulation of the failure severity, high and low). Then, the subjects proceeded to stage 2: the description of recovery process. This stage describes the hotel's dispatch of processing staff (manipulation of the level of service staff) for failure handling. The third stage is to measure the subject's satisfaction with the recovery results and their perception of the corporate image.

A total of 341 subjects were invited to participate. After confirming 4 screening questions (with accommodation experience in the past year and 3 scenario recognition questions), a total of 320 valid questionnaires were collected. Among the subjects, 119 (37.2\%) were male and 201 (62.8\%) were female. The majority were 21-30 years old, with 204 subjects (63.8\%); followed by 31-40 years old, with 34 subjects (10.6\%). The education level was mostly colleges and universities, with 175 subjects (54.7\%); secondly, 79 (24.7\%) were the graduate school or above. In terms of occupation, most of the subjects were students, with135 students (42.2\%), followed by 47 subjects (14.7\%) in the manufacturing industry. In the past year, the number of hotel stays between 1 and 5 was the largest, with 283 subjects (88.4\%), followed by 6 to 10, with 29 subjects $(9.1 \%)$.

\section{Analysis and Results}

\subsection{Reliability and Validity}

Cronbach 's alpha of PRS and corporate image were 0.967 and 0.954 , respectively, indicating these two constructs have a high degree of internal consistency (Wortzel, 1979). Validity refers to the correctness of the research model by a measurement tool; that is, the degree to which the measurement tool can accurately measure the traits or attributes that need to be truly measured ( $\mathrm{Wu}, 2011)$. The factor loadings of a total of 9 items for both constructs are shown in Table 1, and all are greater than 0.9. As judged by the judgment threshold of greater than 0.7 , these two constructs are both in conformity with the convergence validity (Hair, Anderson, Tatham, \& Black, 2009). 
Table 1. Scale items and measured properties.

\begin{tabular}{l|l|l|l|l|l|l}
\hline Construct & Items & Mean & S. D. & Factor loading & Composite reliability & Cronbach's alpha \\
\hline \multirow{5}{*}{ PRS } & PRS1 & 5.106 & 1.412 & 0.936 & & \\
& PRS2 & 5.303 & 1.447 & 0.953 & & \\
& PRS3 & 5.369 & 1.399 & 0.958 & 0.975 & \\
& PRS4 & 5.263 & 1.436 & 0.956 & & \\
& PRS5 & 5.125 & 1.485 & 0.901 & & \\
Corporate image & CI1 & 5.075 & 1.313 & 0.923 & & \\
& CI2 & 5.272 & 1.281 & 0.933 & 0.954 \\
\hline
\end{tabular}

\subsection{Hypotheses Testing}

\subsubsection{Impact on PRS}

First, the correlation between high and low star ratings and PRS was checked. As shown in Table 2, the average mean of five-star PRS is significantly higher than the average mean of one-star PRS $\left(\mathrm{Mean}_{\text {five-stars }}=5.381>\right.$ Mean $_{\text {one-star }}=5.085 ; \mathrm{t}=1.971 *$, which means the higher the star rating, the greater the improvement in satisfaction with service failures. Thus, $\mathrm{H} 1$ is supported. Then, the correlation between personnel rank and PRS was examined. Table 2 shows that the average PRS of high-level service personnel is significantly higher than the average PRS of low-level service personnel $\left(\mathrm{Mean}_{\text {high }}=5.386>\mathrm{Mean}_{\text {low }}=5.080 ; \mathrm{t}=2.038^{*}\right)$, which verifies that the handling of service failures by high-level service personnel helps increase consumer satisfaction. Thus, $\mathrm{H} 2$ is supported. Finally, the relationship between the severity of the failure and the PRS was examined. It can be seen from the data presented in Table 2 that the severity of the failure has not significantly affected the PRS $\left(\mathrm{Mean}_{\text {high }}=5.138<\mathrm{Mean}_{\text {low }}=5.329 ; \mathrm{t}=-1.268\right)$, which means that the severity of the failure had no direct impact on post-recovery satisfaction. Consequently, H3 is not supported.

Table 2. The mean PRS and testing results of three factors

\begin{tabular}{cccccc}
\hline Dependent variable: PRS & Mean (I) & Mean $(\mathrm{J})$ & Mean difference (I-J) & T & P \\
\hline $\begin{array}{c}\text { Star rating } \\
\text { (I=five stars, J=one star })\end{array}$ & $\begin{array}{c}5.381 \\
(\mathrm{n}=160)\end{array}$ & $\begin{array}{c}5.085 \\
(\mathrm{n}=160)\end{array}$ & 0.296 & 1.971 & $0.049^{*}$ \\
\hline $\begin{array}{c}\text { Personnel rank } \\
(\mathrm{I}=\text { high, } \mathrm{J}=\text { low })\end{array}$ & $\begin{array}{c}5.386 \\
(\mathrm{n}=160)\end{array}$ & $\begin{array}{c}5.080 \\
(\mathrm{n}=160)\end{array}$ & 0.306 & 2.038 & $0.042^{*}$ \\
\hline $\begin{array}{c}\text { Severity of failure } \\
(\mathrm{I}=\text { high, } \mathrm{J}=\text { low })\end{array}$ & $\begin{array}{c}5.138 \\
(\mathrm{n}=160)\end{array}$ & $\begin{array}{c}5.329 \\
(\mathrm{n}=160)\end{array}$ & -0.011 & -1.268 & 0.206 \\
\hline Note: $* \mathrm{p}<0.05 ; * * \mathrm{P}<0.01 ; * * * \mathrm{p}<0.001$ & & & &
\end{tabular}

Note: ${ }^{*} \mathrm{p}<0.05 ; * * \mathrm{P}<0.01 ; * * * \mathrm{p}<0.001$

\subsubsection{Impact on Corporate Image}

This section mainly discusses the impact of company recovery on corporate image. First the correlation between high and low star ratings and corporate image was checked. As shown in Table 3, the average mean of 5-star corporate images is significantly higher than the average mean of 1-star corporate images $\left(\mathrm{Mean}_{\text {five-stars }}=5.355>\right.$ $\left.\mathrm{Mean}_{\text {one-star }}=4.989 ; \mathrm{t}=2.682^{* *}\right)$, indicating that when hotels perform recovery, high-star hotels are more likely to enhance corporate image than low-star hotels. Thus, H4 is supported. Regarding the correlation between personnel rank and corporate image, Table 3 shows that the average mean of corporate images of high-level service personnel is significantly higher than the average mean of corporate images of low-level service personnel $\left(\mathrm{Mean}_{\text {high }}=5.309>\mathrm{Mean}_{\text {low }}=5.034 ; \mathrm{t}=2.008^{*}\right)$, which means the handling of service failure by high-level personnel can enhance corporate image. Accordingly, H5 is supported. Then, this study verifies the correlation between the severity of the failure and the corporate image. According to the data in Table 3, high severity is more detrimental to corporate image than low severity service failures $\left(\mathrm{Mean}_{\text {high }}=5.023<\mathrm{Mean}_{\text {low }}=\right.$ $\left.5.320 ; \mathrm{t}=-2.169^{*}\right)$. As learned from the data in Table 3 , the service failures of high severity are more detrimental to corporate image than service failures of low severity, which means that the severity of the failure will have different degrees of impact on corporate image. Consequently, H6 is supported. 
Table 3. The mean corporate image and testing results of three factors

\begin{tabular}{cccccc}
\hline $\begin{array}{c}\text { Dependent variable: } \\
\text { corporate image }\end{array}$ & Mean (I) & Mean (J) & Mean difference (I-J) & T & P \\
\hline $\begin{array}{c}\text { Star rating } \\
\text { (I=five stars, J=one star })\end{array}$ & $\begin{array}{c}5.355 \\
(\mathrm{n}=160)\end{array}$ & $\begin{array}{c}4.989 \\
(\mathrm{n}=160)\end{array}$ & 0.366 & 2.682 & $0.008^{* *}$ \\
\hline $\begin{array}{c}\text { Personnel rank } \\
(\mathrm{I}=\text { high, J = low })\end{array}$ & $\begin{array}{c}5.309 \\
(\mathrm{n}=160)\end{array}$ & $\begin{array}{c}5.034 \\
(\mathrm{n}=160)\end{array}$ & 0.275 & 2.008 & $0.046^{*}$ \\
\hline $\begin{array}{c}\text { Severity of failure } \\
(\mathrm{I}=\text { high, J = low })\end{array}$ & $\begin{array}{c}5.023 \\
(\mathrm{n}=160)\end{array}$ & $\begin{array}{c}5.320 \\
(\mathrm{n}=160)\end{array}$ & -0.297 & -2.169 & $0.031^{*}$ \\
\hline
\end{tabular}

Note: ${ }^{*} \mathrm{p}<0.05 ; * * \mathrm{P}<0.01 ; * * * \mathrm{p}<0.001$

\subsubsection{Impact of PRS on Corporate Image}

In order to verify the correlation between PRS and corporate image, this study used regression analysis. It can be seen from Table 4 that the regression model can explain $61.8 \%$ of variation $\left(\mathrm{R}^{2)}\right.$, which exceeds the threshold of $\mathrm{R}^{2}$ greater than 0.5 , as proposed by scholars, indicating that the fit of this regression model is good (See, et al., 2010). Table 4 shows that the regression coefficient of PRS is 0.786 , and the p value is less than 0.05 , indicating that the two variables of PRS and corporate image have reached significant positive correlation. It means that the more satisfied consumers are with the recovery, the more it will help improve the corporate image. Accordingly, H7 is supported.

Table 4. The result of regression analysis

\begin{tabular}{llll}
\hline \multicolumn{4}{c}{ Dependent variable: Corporate image } \\
\hline Independent variable & Coefficient & t-valve & $\mathrm{p}$ valve \\
\hline PRS & 0.786 & 22.660 & $0.000 * * *$ \\
\hline $\mathbf{R}^{2}=\mathbf{0 . 6 1 8} ; \mathbf{R}^{2}=\mathbf{0 . 6 1 6} ; \mathbf{F}=\mathbf{5 1 3 . 4 8 5} ; \mathbf{d f}=\mathbf{1}$ & & \\
\hline Note: ${ }^{*} \mathrm{p}<0.05 ; * * \mathrm{P}<0.01 ; * * \mathrm{p}<0.001$ &
\end{tabular}

\section{Discussion and Conclusions}

\subsection{Conclusions}

This study treated guests who had stayed in hotels in the previous year as the research subjects, and used the star rating of the hotel, the rank of service staff, and the severity of service failures to explore the impact on post-recovery satisfaction and corporate image. The results of this study aim to provide more practical advice to the hotel industry from a different perspective than those in the past. The study found that different hotel stars have different recovery effects. The recovery by high-star hotels obtains more customer satisfaction than low-star hotels, and their image is better improved. From this finding, it can be seen that the higher the star-rated hotel, the higher the customer's expected service quality of the company; in order to avoid customer dissatisfaction, the high-star hotel must pay more attention to customer service quality and establish a more complete failure handling mechanism (Tsao, 2018).

This study also shows that the level of personnel who deal with mistakes will have different effects on customers' perception of recovery; especially, the higher the level of the handler, the higher the degree of authorization, and failures can be cleared in a more flexible, real-time, transparent, and efficient manner, and customers can know more procedural fairness, which will help improve satisfaction and strengthen the positive corporate image (Tsao et al., 2014).

From the perspective of the research of failures, the different degrees of severity of failures will have significant impact on corporate image; that is, when the failure is more serious, even if the recovery is completed, a larger failure will still have a serious negative impact on the hotel image than an event with less failure. However, the correlation between the severity of the failure and PRS was not confirmed in this study. 
Finally, this study also confirmed a positive correlation between PRS and corporate image, which means that the recovery effect will affect customers' perception and judgment of the company, and it will have significant impact on the maintenance and improvement of the corporate image. It can be seen from the above that mistakes in the service industry are inevitable, but with good recovery mechanisms, it is still possible to maintain the corporate image by creating a second customer satisfaction (McColloug et al., 2000).

\subsection{Marketing Implications and Contributions}

This study offers the following suggestions based on the findings. (1) From the perspective of hotel star rating, if a service failure occurs, the recovery measures of high-star hotels will make guests perceive higher satisfaction and corporate image than that of low-star hotels. Therefore, for high-star hotels, the training of service personnel, the execution of service operations, and the formulation and implementation of fault recovery policies and procedures must be more in place and firm. (2) From the perspective of personnel rank, if a service failure occurs, high-level service personnel can make guests feel higher satisfaction and better corporate image after recovery measures than low-level service personnel. Therefore, for hotels, senior executives must often make inspections in the area under their jurisdiction to respond immediately when a failure occurs. (3) From the perspective of the severity of the failure, if a service failure occurs, an event with a large failure is more likely to cause consumers to have a negative impact on the corporate image than an event with a small failure. Therefore, it is necessary for hotels to formulate measures for recovery of failures, while strengthening the education and training of employees and simulating situations to enhance employee familiarity and reduce the failure rate.

\subsection{Limitations and Directions for Further Research}

Due to the experimental design used in this study, although we tried to achieve rigorous experimental manipulation during the research, we still had the following problems: (1) The quasi-experimental design approach was adopted to facilitate the convenience of sample exposure and provide the subjects with a real feeling of the experimental environment, thus, this study performed a field experiment to perform the experiment and collect subject responses (Wu \& Lin, 2001). The location of the field experiment was not in the laboratory, thus, we may not have controlled all the variables, which renders the internal effect of the experiment less rigorous than the laboratory. (2) The majority of the subjects are students in this study, thus, the application of the results may be limited. (3) This study conducted non-random sampling using social websites to recruit voluntary participants to join the study. In order to overcome non-random sampling leading to the bias of research inference, the eight experimental scenario hyperlinks set in this study were randomly replaced every week to minimize the non-random sampling effect (Tsao, 2018). (4) Although three antecedents were included in this research model to explore the direct influence on the effectiveness of recovery, we feared that other important leading variables or moderators may be ignored.

Based on the above research limitations or deficiencies, this study proposed several research recommendations for reference by future studies. (1) The interaction between the three independent variables can be analyzed in the hope of obtaining other different insights from the perspective of interference variables. (2) The handling of service failures is full of personnel interactions. With this in mind, this study proposed that emotions (including employees and guests) should be included in this research model, in an effort to obtain more valuable and practical conclusions and suggestions.

\section{Acknowledgments}

The authors wish to thank the Ministry of Science and Technology of Taiwan for providing financial support (NSC 107-2813-C-167-005-H).

\section{References}

Adams, J. S. (1963). Towards an understanding of inequity. The Journal of Abnormal and Social Psychology, 67(5), 422. https://doi.org/10.1037/h0040968

Ariffin, A. A. M., \& Maghzi, A. (2012). A preliminary study on customer expectations of hotel hospitality: Influences of personal and hotel factors. International Journal of Hospitality Management, 31(1), 191-198. https://doi.org/10.1016/j.ijhm.2011.04.012

Bhavani, M. G. (2013). Customer's expectations of hospitality services-A study on five star hotels in Hyderabad city. Journal of Management \& Science, 3(4), 16-22. https://doi.org/10.26524/jms.2013.54

Bitner, M. J., Booms, B. H., \& Tetreault, M. S. (1990). The service encounter: diagnosing favorable and unfavorable incidents. Journal of marketing, 54(1), 71-84. https://doi.org/10.1177/002224299005400105

Blodgett, J. G., Hill, D. J., \& Tax, S. S. (1997). The effects of distributive, procedural, and interactional justice 
on post complaint behavior. Journal of retailing, 73(2), 185-210.

https://doi.org/10.1016/S0022-4359(97)90003-8

Brown, M., \& Worcester, R. M. (1972). Print Media Research Objectives and Applications. Consumer Market Research Handbook. London: McGraw-Hill, 548-76.

Byun, J., \& Chatterjee, S. (2004). A strategic pricing for quality of service (QoS) network business. AMCIS 2004 Proceedings, 306.

Chen, H. T. (2009). The importance of front-line service personnel. Journal of Taiwan Fertilizer, 50(2). Retrieved from http://www.taifer.com.tw/taifer/tf/050002/53.html

Chen, H. T., Chen, C. W., Chang, H. F., \& Wang, C. H. (2018). A Study on the Relationship between Service Failure, Corporate Image and Loyalty -Taking Restaurant Industry as an Example. Journal of Island Tourism Research, 11(4), 39-72.

Clark, G. L., Kaminski, P. F., \& Rink, D. R. (1992). Consumer complaints: Advice on how companies should respond based on an empirical study. Journal of Consumer Marketing, 9(3), 5-14. https://doi.org/10.1108/07363769210035189

del Río-Lanza, A. B., Vázquez-Casielles, R., \& Díaz-Martín, A. M. (2009). Satisfaction with service recovery: Perceived justice and emotional responses. Journal of Business Research, 62(8), 775-781. https://doi.org/10.1016/j.jbusres.2008.09.015

Dowling, G. R. (1986). Managing your corporate images. Industrial marketing management, 15(2), 109-115. https://doi.org/10.1016/0019-8501(86)90051-9

Drucker, P. F. (1993). Managing for the Future. Routledge.

Fornell, C. (1992). A national customer satisfaction barometer: The Swedish experience. Journal of marketing, 56(1), 6-21. https://doi.org/10.1177/002224299205600103

Goodwin, C., \& Ross, I. (1992). Consumer responses to service failures: Influence of procedural and interactional fairness perceptions. Journal of Business research, 25(2), 149-163. https://doi.org/10.1016/0148-2963(92)90014-3

Grönroos, C. (2000). Services Management and Marketing: A Customer Relationship Approach (2nd ed.). UK: Wiley.

Hair, J. F., Anderson, R. E., Tatham, R. L., \& Black, W. C. (2009). Multivariate data analysis. Englewood Cliffs, NJ: Prentice Hall.

Hart, C. W., Heskett, J. L., \& Sasser, J. W. (1990). The profitable art of service recovery. Harvard business review, 68(4), 148-156.

Hartline, M. D., \& Ferrell, O. C. (1996). The management of customer-contact service employees: An empirical investigation. Journal of marketing, 60(4), 52-70. https://doi.org/10.2307/1251901

Hess, R. L. (2008). The impact of firm reputation and failure severity on customers' responses to service failures. Journal of Services Marketing, 22(5), 385-398. https://doi.org/10.1108/08876040810889157

Hoffman, K. D., \& Kelley, S. W. (2000). Perceived justice needs and recovery evaluation: a contingency approach. European Journal of marketing, 34(3/4), 418-433. https://doi.org/10.1108/03090560010311939

Hoffman, K. D., Kelley, S. W., \& Rotalsky, H. M. (1995). Tracking service failures and employee recovery efforts. Journal of Services Marketing, 9(2), 49-61. https://doi.org/10.1108/08876049510086017

Hsieh, J. K. (2016). The effect of frontline employee co-creation on service innovation: comparison of manufacturing and service industries. Procedia-Social and Behavioral Science, S, 224, 292-300. https://doi.org/10.1016/j.sbspro.2016.05.488

Huppert, J. W., Arenson, S. J., \& Evans, R. H. (1978). An application of equity theory to buyer-seller exchange situations. Journal of marketing research, 15(2), 250-260. https://doi.org/10.1177/002224377801500208

Keller, K. L. (2000). Building and managing corporate brand equity. The Expressive Organization, Oxford University press: Oxford, 116-137.

Knutson, B. J. (1988). Frequent travelers: Making them happy and bringing them back. Cornell Hotel and Restaurant Administration Quarterly, 29(1), 82-87. https://doi.org/10.1177/001088048802900121

Lewis, B. R., \& McCann, P. (2004). Service failure and recovery: evidence from the hotel industry. International 
Journal of Contemporary Hospitality Management, 16(1), 6-17. https://doi.org/10.1108/09596110410516516

Mattila, A. S. (1999). An examination of factors affecting service recovery in a restaurant setting. Journal of Hospitality \& Tourism Research, 23(3), 284-298 https://doi.org/10.1177/109634809902300304.

Maxham III, J. G., \& Netemeyer, R. G. (2002). Modeling customer perceptions of complaint handling over time: the effects of perceived justice on satisfaction and intent. Journal of retailing, 78(4), 239-252. https://doi.org/10.1016/S0022-4359(02)00100-8

McCollough, M. A., Berry, L. L., \& Yadav, M. S. (2000). An empirical investigation of customer satisfaction after service failure and recovery. Journal of service research, 3(2), 121-137. https://doi.org/10.1177/109467050032002

Nguyen, N., \& Leblanc, G. (2001). Corporate image and corporate reputation in customers' retention decisions in services. Journal of retailing and Consumer Services, 8(4), 227-236. https://doi.org/10.1016/S0969-6989(00)00029-1

Öğüt, H., \& Onur Taş, B. K. (2012). The influence of internet customer reviews on the online sales and prices in hotel industry. The Service Industries Journal, 32(2), 197-214. https://doi.org/10.1080/02642069.2010.529436

Palmer, A., Beggs, R., \& Keown-McMullan, C. (2000). Equity and repurchase intention following service failure. Journal of Services Marketing, 14(6), 513-528. https://doi.org/10.1108/08876040010347624

Parasuraman, A., Zeithaml, V. A., \& Berry, L. L. (1988). SERVQUAL: A multiple-item scale for measuring consumer perceptions of service quality. Journal of retailing, 64(1), 12-40.

Petty, R. E., \& Cacioppo, J. T. (1986). Issue involvement as a moderator of the effects on attitude of advertising content and context. Advances in consumer research, 8(1).

Petzer, D. J., \& Steyn, T. F. J. (2006). Customer retention: A theoretical perspective of service failure and service recovery in the hotel industry. Acta commercii, 6(1), 162-172. https://doi.org/10.4102/ac.v6i1.106

Pranic, L., \& Roehl, W. S. (2012). Rethinking service recovery: A customer empowerment (CE) perspective. Journal of Business Economics and Management, 13(2), 242-260. https://doi.org/10.3846/16111699.2011.620137

Ramanathan, U., \& Ramanathan, R. (2013). Investigating the impact of resource capabilities on customer loyalty: a structural equation approach for the UK hotels using online ratings. Journal of Services Marketing, 27(5), 404-415. https://doi.org/10.1108/JSM-12-2011-0186

Richins, M. L. (1983). An analysis of consumer interaction styles in the marketplace. Journal of consumer Research, 10(1), 73-82. https://doi.org/10.1086/208946

Riordan, C. M., Gatewood, R. D., \& Bill, J. B. (1997). Corporate image: Employee reactions and implications for managing corporate social performance. Journal of Business ethics, 16(4), 401-412. https://doi.org/10.1023/A:1017989205184

Rogg, K. L., Schmidt, D. B., Shull, C., \& Schmitt, N. (2001). Human resource practices, organizational climate, and customer satisfaction. Journal of management, 27(4), 431-449. https://doi.org/10.1177/014920630102700403

See, L. C., Shen, Y. M., Huang, T. M., Chen, C. L., Huang, H. C., Lo, Y. H., \& Lin, S. R. (2010). Validity and Reliability of a Questionnaire Supporting Methadone Maintenance Treatment, Formosan Journal of Medicine, 14(1), 9-17.

Smith, A. K., \& Bolton, R. N. (1998). An experimental investigation of customer reactions to service failure and recovery encounters: paradox or peril? Journal of service research, 1(1), 65-81. https://doi.org/10.1177/109467059800100106

Smith, A. K., Bolton, R. N., \& Wagner, J. (1999). A model of customer satisfaction with service encounters involving failure and recovery. Journal of marketing research, 36(3), 356-372. https://doi.org/10.1177/002224379903600305

Stapp, T. (2012). Reach for the STARS, Entrepreneur, 40(5), 101-117.

Su, C. S., \& Sun, L. H. (2007). Taiwan's hotel rating system: A service quality perspective. Cornell Hotel and Restaurant Administration Quarterly, 48(4), 392-401. https://doi.org/10.1177/0010880407305836 
Tefera, O., \& Govender, K. (2015). Hotel grading, service quality, satisfaction and loyalty-Proposing a theoretical model and relationship. African journal of hospitality, tourism and leisure, 4, 1-17.

Tourism Bureau. (2008). Star hotel evaluation plan”, Ministry of Transportation and Communications. Retrieved from http://admin.taiwan.net.tw/upload/contentFile/201206/hotel_star_16_1.pdf

Tsao, W. C. (2018). Star power: the effect of star rating on service recovery in the hotel industry. International Journal of Contemporary Hospitality Management, 30(2), 1-21. https://doi.org/10.1108/IJCHM-05-2016-0247

Tsao, W. C., \& Jhang, J. Y. (2019). Are Gender and Appearance Important? Exploring the Relationship between Recovery Type and Post-recovery Satisfaction. International Business Research, 12(5), 1-13. https://doi.org/10.5539/ibr.v12n5p1

Tsao, W. C., Hsieh, M. T., Ye, J. S., \& Tsai, C. H. (2014). Loyalty or defection? An Application of equity theory on service recovery in Hospitality Industry: a star rating perspective. In Conference on Sustainable Operation and Development Technology Innovation and Management in a Global Era, LIM007.

Tseng, L. C., \& Chang, Y. J. (2012). A Study of Relationships of Customer Perceived Quality, Experience Value, Satisfaction and Loyalty-Cases of the Hotel in Areas of Kaohsiung and Tainan. Chia Nan Annual Bulletin: Humanity, 38, 347-365.

Walters, C. G., \& Paul, G. W. (1970). Consumer behavior: An integrated framework. RD Irwin.

Wortzel, L. (1979). Multivariate Analysis, Prentice-Hall, NJ.

Wu, W. E. (2011). Business Research Methods. Wha-Tai publishing, Taipei, Taiwan

Wu, W. E., \& Lin, C. H. (2001). Business Research Methods. Wha-Tai publishing, Taipei, Taiwan

Yoo, C., Park, J., \& MacInnis, D. J. (1998). Effects of store characteristics and in-store emotional experiences on store attitude. Journal of Business Research, 42(3), 253-263.

https://doi.org/10.1016/S0148-2963(97)00122-7

Yu, L. (1992). Seeing stars: China's hotel-rating system. Cornell Hotel and Restaurant Administration Quarterly, 33(5), 24-25. https://doi.org/10.1177/001088049203300522

Zeithaml, V. A., Bolton, R. N., Deighton, J., Keiningham, T. L., Lemon, K. N., \& Petersen, J. A. (2006). Forward-looking focus: can firms have adaptive foresight? Journal of Service Research, 9(2), 168-183. https://doi.org/10.1177/1094670506293731

Appendix A. Measurement Instruments

This appendix contains the statements used in the survey. Respondents were asked to what degree they agree or disagree with these statements on a seven-point Likert scale.

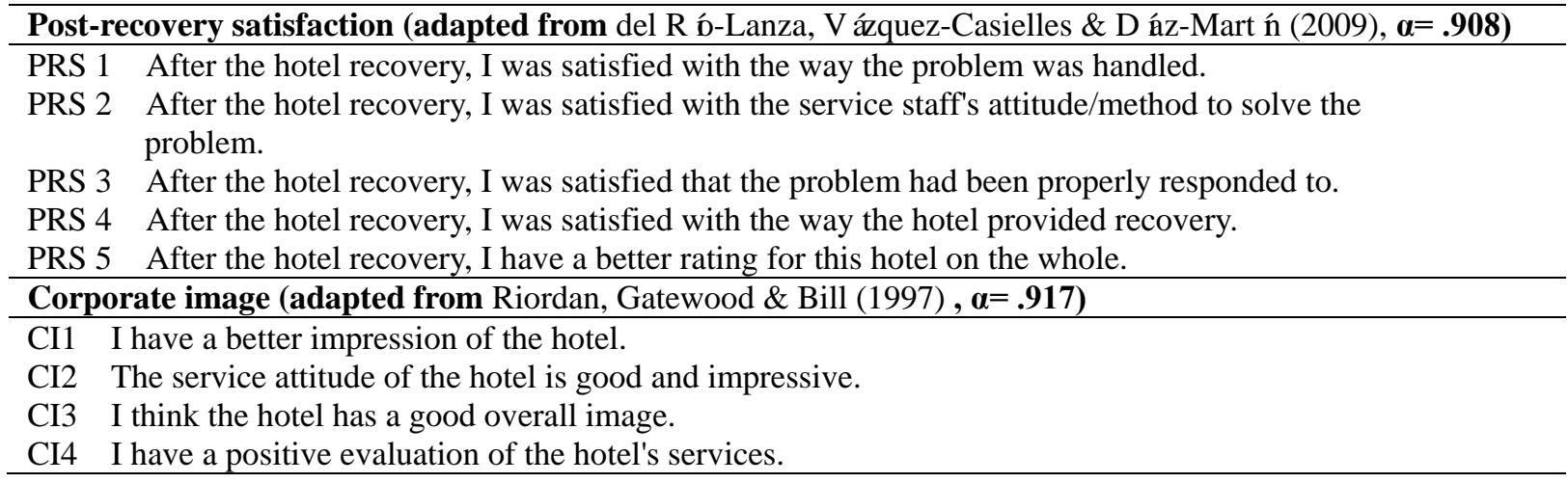

\section{Copyrights}

Copyright for this article is retained by the author(s), with first publication rights granted to the journal.

This is an open-access article distributed under the terms and conditions of the Creative Commons Attribution license (http://creativecommons.org/licenses/by/4.0/). 